Огляди літератури, оригінальні дослідження, погляд на проблему, випадок з практики, короткі повідомлення УДК 616.743.1-009.12-06:616.1/71-053.2

DOI 10.11603/1811-2471.2020.v.i1.11082

\title{
КЛІНІЧНИЙ ВИПАДОК СИНДРОМУ ВЗАЕМНОГО ОБТЯЖЕННЯ ПРИ М'ЯЗОВІЙ КРИВОшиї
}

\author{
Тернопільський національний медичний університет імені І. Я. Горбачевського МОз України
}

РЕзюМЕ. У статті описано випадок запущеного захворювання на м'язову кривошию, яка поєднувалася з цілою низкою іншої супутньої патології скелета дитини та внутрішніх органів - синдром взаємного обтяження.

Наше клінічне спостереження цікаве в тому плані, що легковажне ставлення до кривошиї обумовило значні вторинні деформації опорно-рухового апарату підлітка.

Хвороба була розпізнана у віці 1 рік. Батьки легковажно поставилися до цієї недуги, керуючись принципом "дитина виходиться". Основна увага була прикута до інших захворювань. При детальному обстеженні дитини виявили такі захворювання: природжена правобічна м'язова кривошия; лівобічний кіфосколіз хребта; гемігіпоплазія правої половини обличчя; природжена вада товстої кишки - доліхоколон із зниженням евакуаторної функції кишечника; хронічні запори; енкопрез; пролапс мітрального клапана 1 ст.; дисфункція жовчного міхура за гіперкінетичним типом; міатонічний синдром; Spina bifida S 1.

КЛЮчОВІ СЛОВА: кривошия; кишечник; взаємне обтяження; запори.

Захворювання шиї є одним із найскладніших і найважливіших розділів патології опорно-рухового апарату. Уроджена м'язова кривошия трапляється часто. Незважаючи на численні наукові дослідження, патогенез цієї недуги вивчений недостатньо [1].

Враховуючи перебіг та особливості ранньої діагностики, м'язову кривошию називають «ортопедичним хамелеоном». Тому часто цю недугу діагностують пізно, недооцінюють можливі наслідки захворювання.

У процесі росту дитини нелікована кривошия обумовлює поступове скривлення обличчя, хребта, грудної клітки, черепа. На ранніх етапах захворювання ці зміни мають зворотний характер, у більш старшому віці - незворотний, і залишаються в тій чи іншій мірі на все життя $[1,2]$.

Наше клінічне спостереження цікаве в тому плані, що легковажне ставлення батьків до кривошиї в дитини обумовило значні вторинні деформації опорно-рухового апарату підлітка.

Хлопчик віком 16 років скаржиться на неправильне положення голови, обмеження рухливості шийного відділу хребта. Хворіє з народження. Хвороба була розпізнана у віці 1 рік. Батьки легковажно поставилися до цієї недуги, керуючись принципом «дитина виходиться». Основна увага була прикута до інших захворювань - природжена вада розвитку товстої кишки.

При огляді скарги на запори, періодичний неспокій, каломазання, біль у животі. Схильність до запорів спостерігалася з раннього віку. На даний час затримка випорожнень може сягати до 3-5 днів.

При огляді - загальний стан дитини задовільний. Тіло правильної будови, задовільного живлення.
Голова нахилена вправо, обличчя повернуте вліво, розігнута назад. Права половина обличчя розширена, сплющена, ніс дещо викривлений, деформовані верхня та нижня щелепи, прикус зубів неправильний. Праве плече припідняте, контур шиї справа загострений. Активно та пасивно вивести голову у правильне положення неможливо (функціональні проби з корекцією голови). Шийний відділ хребта скривлений вліво, деформація фіксована. Початкові явища противикривлення хребта вправо на рівні грудного відділу хребта. Шия вкорочена, грудний кіфоз посилений. Правий кивальний м'яз сильно вкорочений, напружений, без ознак запалення. Загальний тонус мускулатури знижений. Виражена гіпермобільність суглобів. Сплощення обох стоп (рис. 1-3).

Живіт дещо піддутий, м'який на усьому протязі, симетричний, чутливий у лівій клубовій ділянці при глибокій пальпації, гази відходять. Перистальтика кишечника звичайна. Печінка дещо збільшена. Тонус сфінктера збережений, дещо знижений.

Іригографія - при введенні барієвої суміші через пряму кишку під контролем екрана відміча$\epsilon$ ться наявність двох додаткових петель сигмоподібної кишки із розширенням у діаметрі. Після випорожнення залишається значна кількість барію в кишечнику, що свідчить про зниження евакуаторної функції. Незрощення дужки першого крижового хребця. Позитивний симптом Пайра.

На УЗД органів живота - збільшення правої частки печінки, перегин шийки і тіла жовчного міхура. ЕКГ, УЗД серця - пролапс мітрального клапана 1 ст. Розлади внутрішньошлуночкової провідності, перевантаження правого шлуночка, гіпоксія міокарда. 


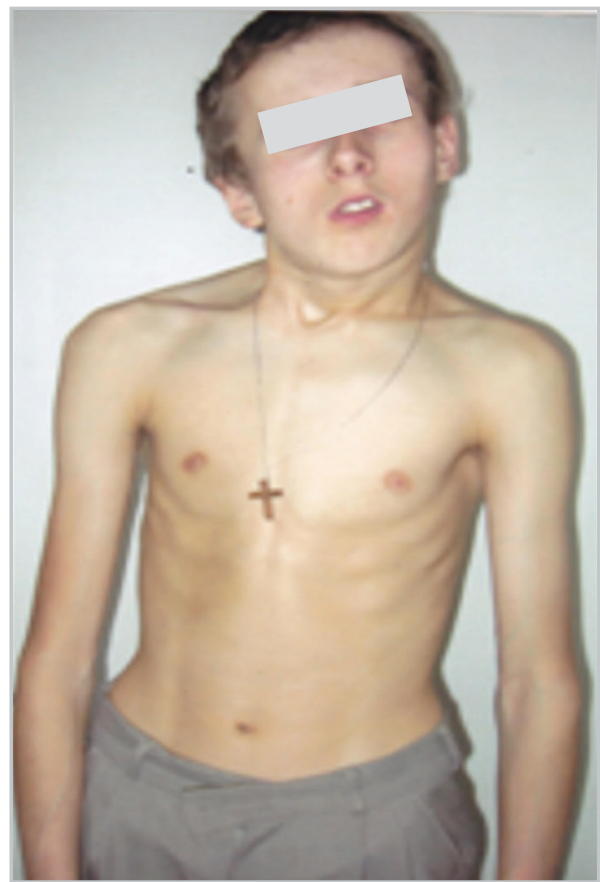

Рис. 1. Хворий Н. Вигляд спереду.

Голова нахилена вправо, асиметрія надпліч, трикутників шиї, деформація тулуба. Гемігіпоплазія правої половини обличчя. Деформація прикусу зубів, обох щелеп, носової перегородки. Вкорочення та напруження правого кивального м'яза. Стійке неправильне положення голови.

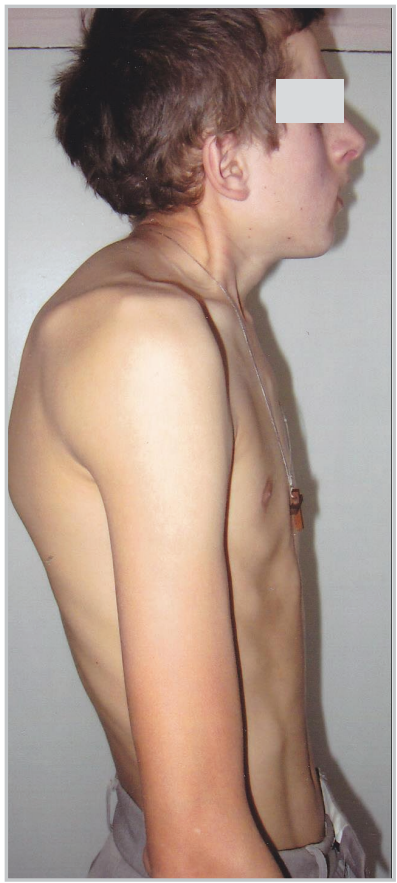

Рис. 2. Хворий Н. Вигляд збоку.

Сильне вкорочення та потовщення правого кивального м'яза. Вкорочення шиї. Фіксований та посилений грудний кіфоз. Сплощення передньої стінки грудної клітки.

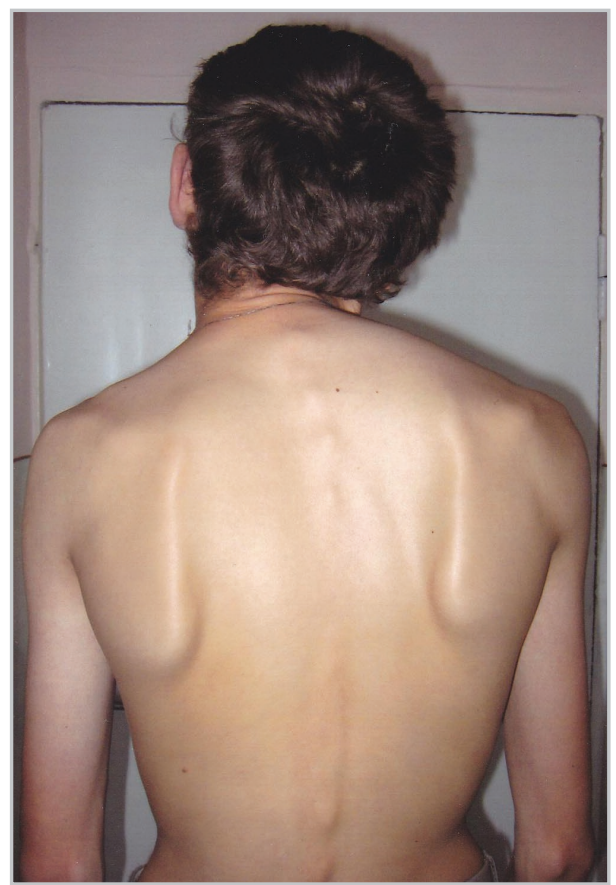

Рис. 3. Хворий Н. Вигляд заду.

Голова нахилена вправо, асиметрія надпліч, трикутників шиї, деформація тулуба. Лівобічне викривлення хребта шийного відділу, правобічне викривлення хребта грудного відділу. Пологий правобічний реберний горб. Асиметрія розташування лопаток. Стійке неправильне положення голови.
Клінічний діагноз. Природжена правобічна м'язова кривошия. Лівобічний кіфосколіоз хребта. Гемігіпоплазія правої половини обличчя. Природжена вада товстої кишкки - доліхоколон із зниженням евакуаторної функції кишечника. Хронічні запори. Енкопрез. Пролапс мітрального клапана 1 ст. Дисфункція жовчного міхура за гіперкінетичним типом. Міатонічний синдром. Spina bifida S 1. Синдром дисплазії сполучної тканини. Синдром гіпермобільності суглобів. Двобічна плоскостопість.

Дитина отримує консервативне фізіотерапевтичне лікування з приводу розладів кишечника. Надана соціальна допомога - інвалід дитинства. Від запропонованого оперативного лікування кривошиї батьки відмовляються.

Більш детально вивчений взаємозв'язок мієлодисплазії попереково-сакрального відділів хребта з розладами іннервації, кровопостачання та розвитку органів черевної порожнини. Недорозвиток хребта на цьому рівні має природжений характер і передається за спадковістю. Тип успадкування уточнюється [3].

Патологічні процеси при даному захворюванні $\epsilon$ результатом цілої низки розладів розвитку сполучної тканини усього організму, які до теперішнього часу майже не вивчені - синдром природже- ної дисплазії сполучної тканини. В англомовній літературі він іменується MASS-синдромом $[4,5]$.

Абревіатура складається з перших букв найтиповіших основних фенотипічних ознак цього синдрому. Mitral valve, Aorta, Skeleton, Skin, тобто виокремлюють чотири основних симптомокомплекси: зв'язково-суглобовий, кістково-м'язовий, шкірний та кардіальний. Ці симптомокомплекси у кожного пацієнта можуть поєднуватися в різних комбінаціях [4-6].

Згідно зі статистичними даними, при MASSсиндромі у 80 \% пацієнтів наявна патологія серцево-судинної системи, зокрема синдром дисплазії сполучної тканини серця (СДСТС), який включає пролапс мітрального клапана (ПМК), пролапс трикуспідального клапана (ПТ), аортального (ПА) та легеневих клапанів (ПЛК), аномально розташовані хорди та інше [4-6].

Перспективи подальших досліджень. Перспективними $\epsilon$ пренатальне обстеження, обстеження новонароджених, тестування на наявність мутантних генів при відсутності симптомів захворювання. Виявити ці захворювання у новонароджених дуже складно, тому такі діти підлягають обов'язковому диспансерному спостереженню 3 поглибленим оглядом вузькими спеціалістами. 
Огляди літератури, оригінальні дослідження, погляд на проблему, випадок з практики, короткі повідомлення ЛІТЕРАТУРА

1. Процайло М. Д. Уроджена м'язова кривошия / М. Д. Процайло. - Тернопіль : Укрмедкнига, 2019. - 59 с.

2. Hefti F. Pediatric Orthopedics in Practice / F. Hefti ; tras. from the German by R. Hinchliffe. Lorrach, 2007.

3. Цапок А. А. Вегетативна та вертебральна дисфункції у дітей / А. А. Цапок // Лікарська справа. - 2015. № 2. - С. 161-162.

4. Чуриліна А. В. Синдром дисплазії сполучної тканини серця у дітей / А. В. Чуриліна // Педіатрія, акушерство та гінекологія. - 2003. - № 1. - С. 20-22.

\section{REFERENCES}

1. Protsailo, M.D. (2019) Urodzhena miazova kryvoshyia [Congenital muscle wryneck]. Ternopil: Ukrmedknyha [in Ukrainian].

2. Hefti, F. (2007). Pediatric Orthopedics in Practice. Tras. from the German by R. Hinchliffe. Lorrach.

3. Tsapok, A.A. (2015). Vehetatyvna ta vertebralna dysfunktsii u ditei [Vegetative and vertebral dysfunction in children]. Likarska sprava - Medical Practice, 2, 161-162 [in Ukrainian].

4. Churylina, A.V. (2003). Syndrom dysplazii spoluchnoi tkanyny sertsia u ditei [Heart connective tissue dysplasia syndrome in children]. Pediatriia, akusherstvo ta hinekolohiia - Pediatrics, Obstetrics and Gynecology, 1, 2022 [in Ukrainian].
5. Омельченко Л. И. Дисплазия соединительной ткани у детей / Л. И. Омельченко, В.Б.Николаенко // Doctor - журнал для практикующих врачей. - 2004. № 1. - C. 44-47.

6. Підхід до диспансерного спостереження дітей з пролапсом мітрального клапана / А. В. Чуріліна, С. П. Атременко, Д. І. Масюта, Л. Ф. Чага ; мат. наук. прак. конф. «Профілактика та реабілітація найбільш поширених захворювань у дітей та удосконалення їх диспансеризації». - К., 2002. -60 c.

\section{КЛИНИЧЕСКИЙ СЛУЧАЙ СИНДРОМА ВЗАИМНОГО ОТЯГОЩЕНИЯ ПРИ МЫШЕЧНОЙ КРИВОШЕЕ}

5. Omelchenko, L.Y, \& Nykolaenko, V.B. (2004). Dysplaziya soedenitelnoy tkani u detey [Dysplasia of connective tissue in children]. Doctor - zhurnal dlya praktykuyushchykh vrachey - Doctor - Journal for Practicing Doctors, 1, 44-47 [in Russian].

6. Churilina, A.V., Atremenko, S.P, Masyuta, D.I, \& Chaha, L.F. (2002). Pidkhid do dyspansernoho sposterezhennia ditei z prolapsom mitralnoho klapana [Approach to dispensary observation of children with mitral valve prolapse]. Materialy naukovo-praktychnoi konferentsii "Profilaktyka ta reabilitatsiia naibilsh poshyrenykh zakhvoriuvan u ditei ta udoskonalennia yikh dyspanseryzatsii" - Proceedings of Scientific and Practical Conference "Prevention and rehabilitation of the most common diseases in children and improvement of their medical examination". Kyiv [in Ukrainian].

๑М. Д. Процайло

Тернопольский национальный медицинский университет имени И. Я. Горбачевского МОз Украины

РЕЗЮМЕ. В статье описан клинический случай запущенной мышечной кривошеи в сочетании с другими сопутствующими заболеваниями скелета ребенка и внутренних органов - синдром взаимного отягощенния.

Наше клиническое наблюдение интересно в том плане, что легкомысленное отношение к кривошее обусловило тяжелые вторичные деформации опорно-двигательного аппарата юноши.

Болезнь была диагностированна в возрасте одного года. Родители легкомысленно однеслись к этому заболеванию по принципу «заболевание пройдет само собой». Главное вниманий приделяли другим болезням. При тщательном обледовании ребенка выявили такие заболевания: врожденная правосторонняя мышечная кривошея; левосторонний кифосколиоз позвоночника; гемигипоплазия правой половины лица; врожденная аномалия развития толстой кишки - долихоколон со сниженной эвакуаторной функцией кишечника; хроничнские запоры; энкопрез; пролапс митрального клапана 1 ст.; дисфункция желчного пузиря по гиперкинетическому типу; миатонический синдром; Spina bifida S 1.

КЛЮчЕВЫЕ СЛОВА: кривошея; кишечник; взаимное отягощение; запоры. 


\section{Horbachevsky Ternopil National Medical University}

SUMMARY. The article describes a case of advanced muscular curvature, which was combined with a number of other concomitant skeletal disorders of the child and internal organs - the mutual burden syndrome.

Our clinical observation is interesting in the sense that frivolous curvature caused significant secondary deformations of the musculoskeletal system of the teenager.

The disease was recognized at the age of 1 year. Parents lightly treated this ailment on the basis of the principle "baby will overgrow it". The main focus was on other diseases. A detailed examination of the child revealed the following diseases: Congenital right-sided muscle torticollis. Left-side kyphoscolysis of the spine. Hemigipoplasia of the right half of the face. Congenital defect of the large intestine - dolichocolon with a decrease in evacuation function of the intestine. Chronic constipation. Encapsulation. Prolapse of mitral valve stage 1. Bladder dysfunction by hyperkinetic type. Myatonic syndrome. Spina bifida S 1.

KEY WORDS: torticollis; intestine; mutual encumbrance; constipation. 